\title{
The study of direct ELISA and competitive ELISA for rabbit metallothionein: correlation of induction with zinc
}

\author{
Liu Ying, Zheng Junheng, Dang Weiwei, Ren Hongwei, Yu Meimin and Ru Binggen \\ National Laboratory of Protein Engineering, College of Life Sciences, Peking University, Beijing 100871, P.R. China
}

\begin{abstract}
On the basis of the purification of metallothionein (MT) from human fetal liver, the purified polyclonal antibody of rabbit anti-human MT-1 was prepared. Direct enzyme-linked immunosorbent assay (ELISA) for MT in rabbit tissues was established. Direct ELISA is a direct binding assay. Its sensitivity is $0.4 \mathrm{ng}(4 \mathrm{ng} / \mathrm{ml})$. MT contents of control rabbit liver and kidney are $240 \mu \mathrm{g} / \mathrm{g}$ and $200 \mu \mathrm{g} / \mathrm{g}$ wet weight tissue, respectively. MT contents of high induction rabbit liver and kidney are $3130 \mu \mathrm{g} / \mathrm{g}$ and $3570 \mu \mathrm{g} / \mathrm{g}$ wet weight tissue, respectively. Competitive ELISA for MT in erythrocyte lysate was determined. Coating concentration is $20 \mathrm{ng} / \mathrm{ml}$; antibody dilution is 1:2000; competitive MT concentrations are $40-2500 \mathrm{ng} / \mathrm{ml}$. Its sensitivity extends to $2 \mathrm{ng}$ $(40 \mathrm{ng} / \mathrm{ml})$. MT concentration in the control rabbit erythrocyte lysate is $10.52 \mu \mathrm{g} / \mathrm{g}$ total lysate protein; it is $43.16 \mu \mathrm{g} / \mathrm{g}$ total lysate protein in the low induction group, and $94.93 \mathrm{mg} / \mathrm{g}$ total lysate protein in the high induction group.
\end{abstract}

(Cd-heme [9-11], mercury-trichloroacetic acid (TCA) [12,13], silver saturation [14]) and high-performance liquid chromatography(HPLC) / atomic absorption spectroscopy (AAS) [15-17]. Their detection limits are about $1 \mu \mathrm{g}$ MT. We present a more simple, specific and sensitive technique, direct ELISA to quantitate MT in tissue cytosols. As little as $0.4 \mathrm{ng}$ of MT can be determined. The ELISA is a direct binding assay.

At present, radioimmunoassay (RIA) [18] and enzymelinked immunosorbent assay (ELISA) incorporating the fluorimetric detection system [19] had been reported for the assay of MT in extracellular fluids like plasma (serum) and urine. Application of RIA for MT had shown that its secretion into plasma and its excretion into urine are affected by many factors, including age, species, nutritional status, liver function and exposure to metals [20-22]. Erythrocyte MT appeared less responsive to stress and infection than plasma MT in experimental animals, so it may be a more stable indicators of zinc status in humans [6]. Recently, we describe a competitive ELISA for rabbit erythrocyte MT. The competitive ELISA is a competitive binding assay without the fluorimetric detection system, and it is safer and less time-consuming than the RIA.

\section{Materials and methods}

Metallothioneins (MTs) are a class of cysteine-rich, lowmolecular weight, metal-binding proteins that are widely found from single-cell organisms to humans [1]. They fold into two separate domains in the presence of certain metal ions [2]: $\alpha$ domain-with four ions and 11 cysteine residues, and adomain-with three ions and 9 cysteine residues [3]. MTs are mainly involved in cellular detoxification of heavy metals such as cadmium and mercury, and in the homeostasis of essential metal ions, e.g. zinc and copper [4]. They can serve as scavengers of free hydroxyl radicals or sources of zinc for DNA repair enzymes, so they are important in mammalian UV response [5]. MT levels in erythrocytes also provide a useful index upon which zinc status in humans can be assessed [6]. Considering their nutritional and toxicological significance, it is useful to quantitate MTs in tissues and other biological media. Several methods for the quantification of MTs in various tissues had been established, such as polarographic analysis $[7,8]$, metal affinity methods

\section{Materials}

Male rabbits, 5 months old, were obtained from the animal centre of College of Life Sciences, Peking University. Tris (Hydroxymethyl) aminomethane, Tween-20, TMB(3,3',5,5'tetramethylbenzidine), ablumin (bovine, Fraction V powder, 98-99 \%) Sigma Co., USA; sheep anti-rabbit IgG-HRP, bovine serum ablumin (BSA) Hua Mei Co., China; DC Protein Assay Kit, Bio-Rad Co.,USA. $\mathrm{ZnSO}_{4}$ (content $\geq 99.0 \%), \quad \mathrm{Na}_{2} \mathrm{CO}_{3}, \quad \mathrm{NaHCO}_{3}, \mathrm{NaCl}, \mathrm{KCl}$, $\mathrm{Na}_{2} \mathrm{HPO}_{4} \cdot 12 \mathrm{H}_{2} \mathrm{O}, \mathrm{NaH}_{2} \mathrm{PO}_{4} \cdot 2 \mathrm{H}_{2} \mathrm{O}, \mathrm{KH}_{2} \mathrm{PO}_{4}$, dimethyl sulfoxide (DMSO), $30 \% \mathrm{H}_{2} \mathrm{O}_{2}, \mathrm{H}_{2} \mathrm{SO}_{4}$, etc. used in this experiment are A.R. products made in China.

96 well ELISA plate, NUNC, F16, Denmark. Minireader, Tecan, Spectra Rainbow, Austria. Atomic absorption spectrometer, Philips, PU9200 model, United Kingdom. 


\section{Methods}

A total of 6 rabbits were participated: 2 in the control (uninduced) group, 2 in the low induction group and 2 in the high induction group. Induction of rabbit MT was conducted by the following two groups. In the low induction group, rabbits were injected subcutaneously with $\mathrm{ZnSO}_{4}$. The dose of $\mathrm{Zn}^{2+}$ was 10.0, 20.0, 30.0, 50.0, 70.0, 100.0, $150.0 \mathrm{mg} / \mathrm{Kg}$ body weight after $1,3,5,8,10,12,15$ days, respectively. In the high induction group, the induction of rabbit MT was performed in the same conditions as above through progressive increasing in $\mathrm{Zn}^{2+}$ dose, i.e. 10.0, 20.0, 50.0, 100.0, $150.0,200.0,250.0 \mathrm{mg} / \mathrm{Kg}$ body weight, respectively. On the sixteenth day 6 rabbits were killed. Livers and kidneys were collected from rabbits. Venous blood samples were drawn in trace elements-free-evacuated tubes containing $0.13 \mathrm{M}$ sodium citrate for the preparation of erythrocytes. The erythrocytes were separated by centrifugation at $3000 \mathrm{rpm}$ for 10 minutes. After inverted several times, the tubes were centrifuged again, and this process was repeated twice. The washed cells were lysed by addition of ice-cold doubly distilled $\mathrm{H}_{2} \mathrm{O}$ (1:1.4). All samples were stored at $-80{ }^{\circ} \mathrm{C}$.

\section{Human metallothionein purification}

Human foetal liver samples were obtained from the Fourth Military Medicine University in China. Preparation of crude fraction was described previously [23]. The lyophilized crude fraction was dissolved in $20 \mathrm{ml} .10 \mathrm{mmol} / \mathrm{L}$ Tris- $\mathrm{HCl}$ $(\mathrm{pH}$ 8.6) and applied to $2.5 \times 90 \mathrm{~cm}$ column of Sephadex G-75 equilibrated with the same buffer. Zinc and copper were determined by atomic absorption spectrophotometry at 213.9 and $324.8 \mathrm{~nm}$, respectively. Fractions containing $\mathrm{Cu}$ and $\mathrm{Zn}$ were pooled, and then applied to DEAE Sepharose Fast Flow $(3.2 \times 10 \mathrm{~cm})$. The column was eluted with a linear gradient from 0.01 to $0.25 \mathrm{~mol} / \mathrm{L}$ Tris- $\mathrm{HCl}(\mathrm{pH} 8.6)$. Fractions containing the two isoforms were pooled separately and then concentrated samples were conducted on a column of Sephadex G-25 $(1.8 \times 50 \mathrm{~cm})$. Finally, the effluents to be collected were lyophilized to obtain the freezedried MT-1 and MT-2. MT-1 prepared by this way was used to produce anti-human MT-1 antiserum.

\section{Production of rabbit anti-human metallothionein-1 IgG}

$1 \mathrm{mg}$ of purified human MT-1 was added to $2 \mathrm{mg}$ of rat $\mathrm{IgG}$ in the $1 \mathrm{ml}$ of $50 \mathrm{mmol} / \mathrm{L}$ sodium phosphate buffer ( $\mathrm{pH} 7.4$ ), and followed by $3.8 \mu \mathrm{l}$ of $25 \%$ (wt/vol.) glutaraldehyde. The mixture was incubated for 2 hours at $23{ }^{\circ} \mathrm{C}$, and then overnight at $4{ }^{\circ} \mathrm{C}$ after the addition of $1.4 \mathrm{ml}$ of $50 \mathrm{mmol} / \mathrm{L}$ sodium phosphate buffer ( $\mathrm{pH}$ 7.4). Just before injection, the milky suspensions were prepared from the mixture of rabbit MT-1 $(400 \mu \mathrm{g})$ with the equal volume of complete Freund's adjuvants. The rabbits were received multiple intradermal and intramuscular injections. Booster injections were given a month after the initial injection using the mixture of rabbit MT-1 $(200 \mu \mathrm{g})$ and incomplete Freund's adjuvants (1:1), and this was repeated 21 days later. The titre of antibody was tested after a week. Blood was collected and allowed to clot for 2 hours at room temperature, then centrifuged at $2500 \mathrm{rpm}$ for 20 minutes to obtain serum. This antiserum was stored at $-80^{\circ} \mathrm{C}$.

$2 \mathrm{ml}$ of antiserum was diluted with 10 vol. of the combination buffer $\left(10 \mathrm{mmol} / \mathrm{L} \mathrm{Na}_{2} \mathrm{HPO}_{4}, 0.15 \mathrm{~mol} / \mathrm{L} \mathrm{NaCl}\right.$, $\mathrm{pH} 8.2$ ) and then applied to a $1.4 \times 2.8 \mathrm{~cm}$ column of protein A agarose [24]. The fractions containing peak absorbency at $280 \mathrm{~nm}$ (rabbit anti-human MT-1 IgG) were pooled and dialyzed for 24 hours against $10 \mathrm{mmol} / \mathrm{L}$ PBS, pH 7.4.

\section{Direct ELISA procedure}

Preparation of heat-treated liver and kidney cytosols was described previously [24]. Dilutions were from 50,000-fold to 100,000 -fold for the heat-treated cytosols above with the coating buffer for the direct ELISA. The negative control lacking any antigen was set [25].

Carbonate-buffered saline solution (50 mmol/L, pH 9.6) was used for coating the ELISA plates. As a washing buffer, it contained phosphate-buffered saline solution (PBS, $10 \mathrm{mmol} / \mathrm{L}, \mathrm{pH} 7.4$ ) and $0.5 \%$ Tween 20. Bovine serum albumin $(3 \%)$ was added to the washing buffer as blocking solution and diluting buffer. $100 \mu \mathrm{l}$ of serial dilutions of purified rabbit MT-1 standard $(4 \sim 20 \mathrm{ng} / \mathrm{ml})$ in the coating buffer, negative control (coating buffer) and unknown samples were respectively added to each well of 96 well microliter plates overnight at $4{ }^{\circ} \mathrm{C}$, and then washed three times. Blocking solution was added (300 $\mu \mathrm{l} /$ well) and incubated for 1 hour at $37{ }^{\circ} \mathrm{C}$ to block nonspecific binding sites. Solutions in each well were discarded. $100 \mu$ of rabbit anti-human MT-1 IgG (1:4000) were placed to each well and incubated for 2.5 hours at $37^{\circ} \mathrm{C}$, and followed by washing three times. $100 \mu \mathrm{l}$ goat anti-rabbit IgG-HRP(1:1000) was added to each well. The plates were incubated for 1 hour at $37^{\circ} \mathrm{C}$ and then washed with the washing buffer three times and with doubly distilled $\mathrm{H}_{2} \mathrm{O}$ twice. $100 \mu \mathrm{l}$ of the enzyme substrate solutions (phosphate buffer, $0.1 \mathrm{~mol} / \mathrm{L}, \mathrm{pH}$ 6.0: TMB, $6.0 \mathrm{mg} / \mathrm{ml}$ DMSO: $\left.30 \% \mathrm{H}_{2} \mathrm{O}_{2}=100: 1.0: 0.15\right)$ were added to each well and followed by 15 minutes incubation at $37^{\circ} \mathrm{C}$. The reaction was stopped by addition of $2 \mathrm{~mol} / \mathrm{L} \mathrm{H}_{2} \mathrm{SO}_{4}$ and optical densities (O.D.) were read at $450 \mathrm{~nm}$ by using an automatic minireader (Tecan).

\section{Competitive ELISA procedure}

The competitive assay was performed as previously described [24]. We optimised for coating concentrations for rabbit MT-1 and rabbit anti-human MT-1 IgG. OD $_{450}$ were measured when four rabbit anti-human MT-1 IgG dilutions (1000 8000-fold) and five rabbit MT-1 coating concentrations $(10,20,50,100,200 \mathrm{ng} / \mathrm{ml})$ were added to each well with competing rabbit MT-1 concentration equal to zero. $20 \mathrm{ng} / \mathrm{ml} / 1: 2000,50 \mathrm{ng} / \mathrm{ml} / 1: 2000,50 \mathrm{ng} / \mathrm{ml} / 1: 4000$, $100 \mathrm{ng} / \mathrm{ml} / 1: 4000$ (coating concentration/antibody dilution) were chosen for subsequent measurements. Competing rabbit MT-1 concentrations from 40 to $2500 \mathrm{ng} / \mathrm{ml}$ produced approximate linear changes in percent binding. Protein concentrations of the erythrocyte lysate were determined by DC 
Protein Assay Kit [26]. 0.3-1.8mg/ml albumin was used as standards in the protein assay. Appropriate dilutions of erythrocyte lysate were used to competitive assay.

\section{Results and discussions}

\section{Human metallothionein purification}

Gel filtration chromatography of crude fraction of human embryo livers shows that the major $\mathrm{Zn}, \mathrm{Cu}$-containing fractions were predominantly MT (Fig. 1). Furthermore, human MT-1 and MT-2 isoforms were isolated and purified by DEAE-Sepharose Fast Flow, MT-1 peak containing Zn and $\mathrm{Cu}$, MT-2 peak containing Zn only (Fig. 2). Amino acid composition of MT-1 was determined and the result was as expected.

\section{The reaction specificity of Rabbit anti-human MT-1 polyclonal antibody}

HRP-labeled MT-1 polyclonal antibody raised in rabbit had been produced for ELISA. Figure 3 shows that the rabbit anti-human MT-1 polyclonal antibody does not cross-react with BSA, Hb and MT from snails; on the contrary, this antibody cross-reacts well with MT from rabbits, rats, hedgehogs and humans. This disparity is probably attributable to species difference because the antibody is specific for mammal MTs. Similar results were reported by Arthur using the human MT-1 ELISA to purified human MT-2 and rat MT-1 isoforms [24].

\section{Use of direct ELISA to quantitate rabbit tissue metallothionein}

Although ELISAs had been used for the quantification of MT [24,25,27], they are almost competitive binding assays. In this report, the direct ELISA is a direct binding assay. An unknown antigen or MT standards in the solid phase directly binds with a primary antibody. Its sensitivity is $0.4 \mathrm{ng}$ (4 ng/ml). It is more simple, specific and sensitive than polarographic analysis, metal affinity methods and HPLC/AAS. Determination of MT concentration in crude tissue fractions had been established. Figure 4 showed the relationship between serial dilutions of purified rabbit MT-1 concentrations (4-20 $\mathrm{ng} / \mathrm{ml})$ and O.D. values at $450 \mathrm{~nm}$. Concentrations obtained from serial dilutions of heat-treated liver and kidney cytosols were deduced by the above standard curve (Fig. 4). Results from the control and high induction group are shown in table I. The MT levels in the control rabbit liver and kidney are $240 \mu \mathrm{g} / \mathrm{g}$ wet weight tissue and $200 \mu \mathrm{g} / \mathrm{g}$, respectively.

It was reported that MT levels in the normal human liver was $1035 \pm 214 \mu \mathrm{g} / \mathrm{g}$ [24], $18 \mu \mathrm{g} / \mathrm{g}$ in the normal rat liver [28]. The disparity is probably attributable to species difference. This fact that MT levels in human tissues and fluids are higher than generally observed in the rat has been demonstrated by others for normal human livers [29,30].

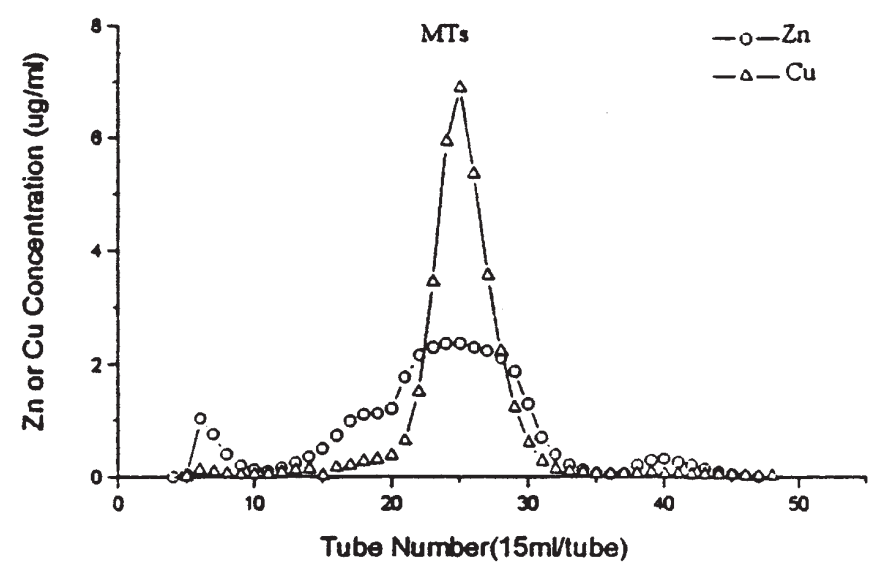

Figure 1. Sephadex G-75 chromatography of human fetal liver metallothioneins. Column: $2.5 \times 90 \mathrm{~cm}$; flow rate: $60 \cdot \mathrm{ml} \mathrm{h}^{-1}$.

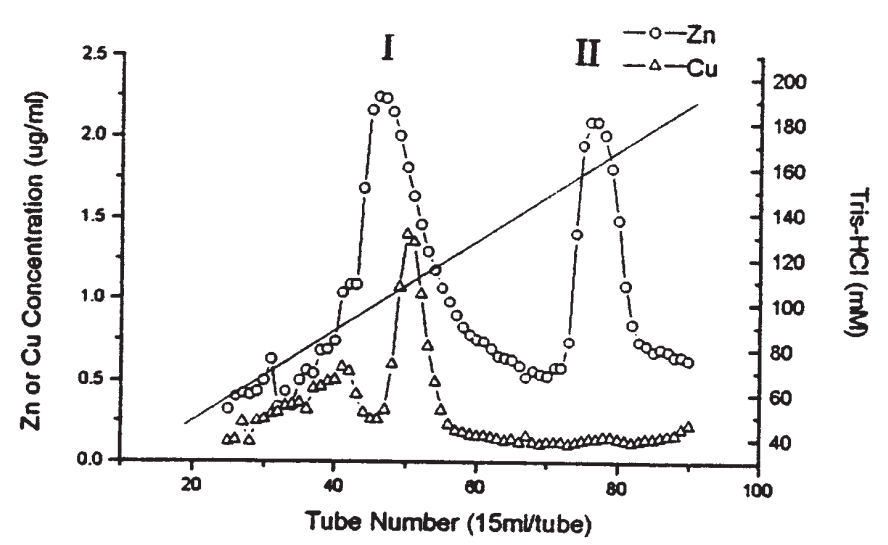

Figure 2. Ion exchange chromatography of metallothioneins on DEAE-Sepharose. Column: $3.2 \times 10 \mathrm{~cm}$; elution with the linear gradient of Tris-Hcl (pH 8.6). (A buffer: $0.01 \mathrm{M}, 1000 \mathrm{ml}$; B buffer: $0.25 \mathrm{M}, 1000 \mathrm{ml}$ ) at a flow rate of $120 \mathrm{ml}^{-1}$. (I: MT-1; II: MT-2).

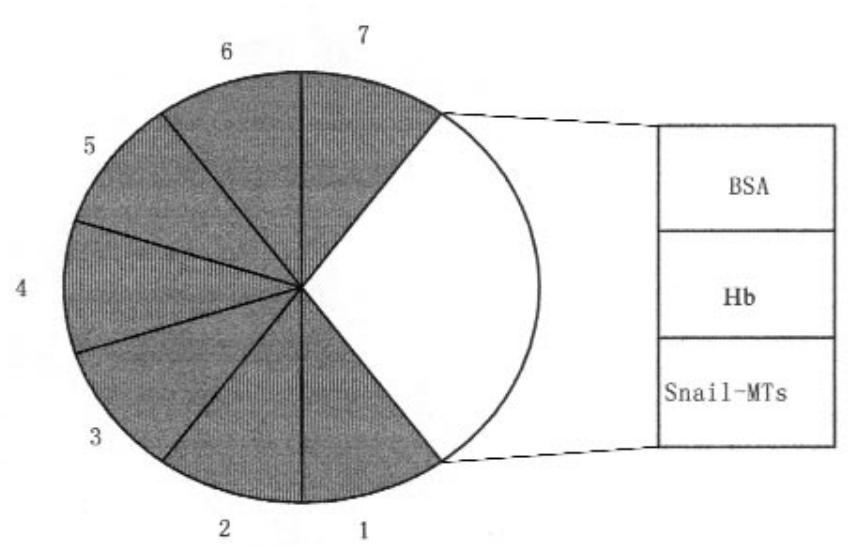

Figure 3. The reaction specificity of rabbit anti-human MT-1 polyclonal antibody. The antibody cross-reacts well with human MT2(1), hedgehog MT-1(2), hedgedog MT-2(3), rat MT-1(4), rat MT2(5), rabbit MT-1(6) and rabbit MT-2(7). It didn't cross-react with BSA, $\mathrm{Hb}$ and snail MTs by ELISA. (BSA: bovine serum ablumin; $\mathrm{Hb}$ : hemoglobin). 


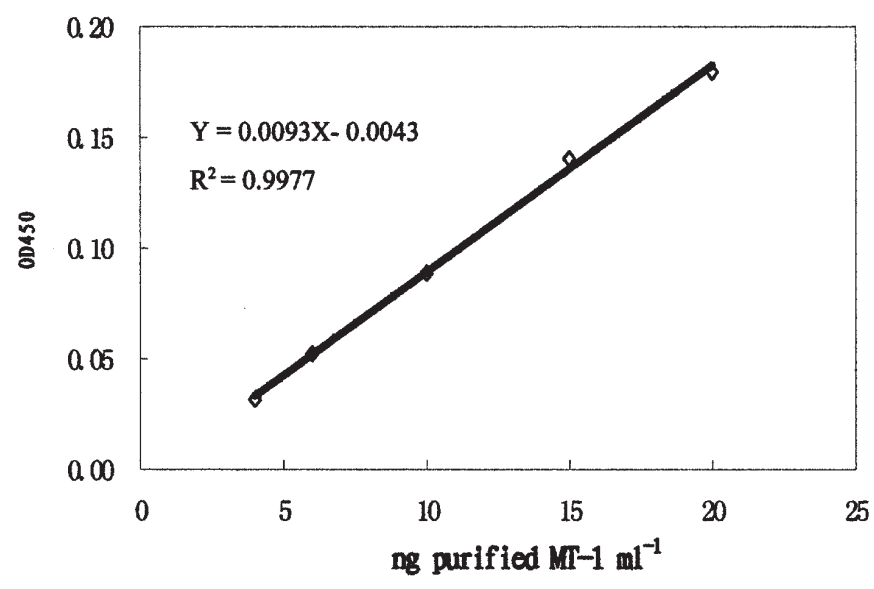

Figure 4. A purified rabbit MT-1 standard curve for direct ELISA.

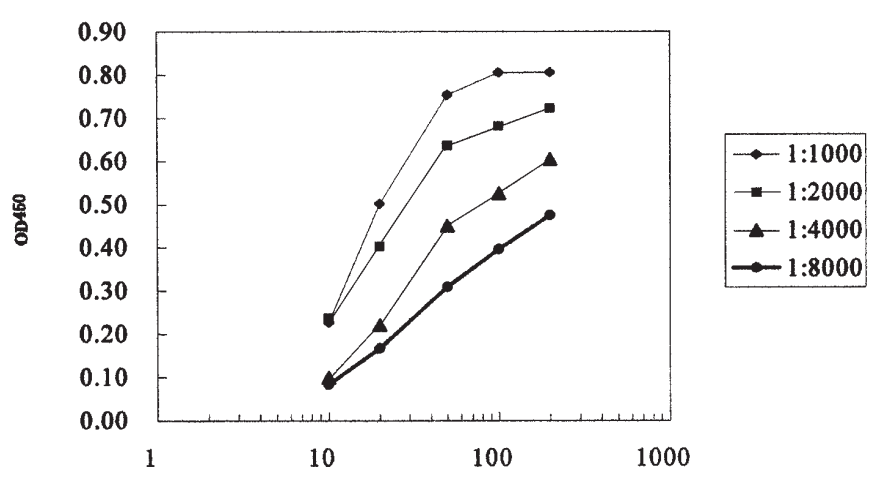

Figure 5. ELISA was optimized for coating concentrations for rabbit MT-1 and rabbit anti-human MT-1 IgG.

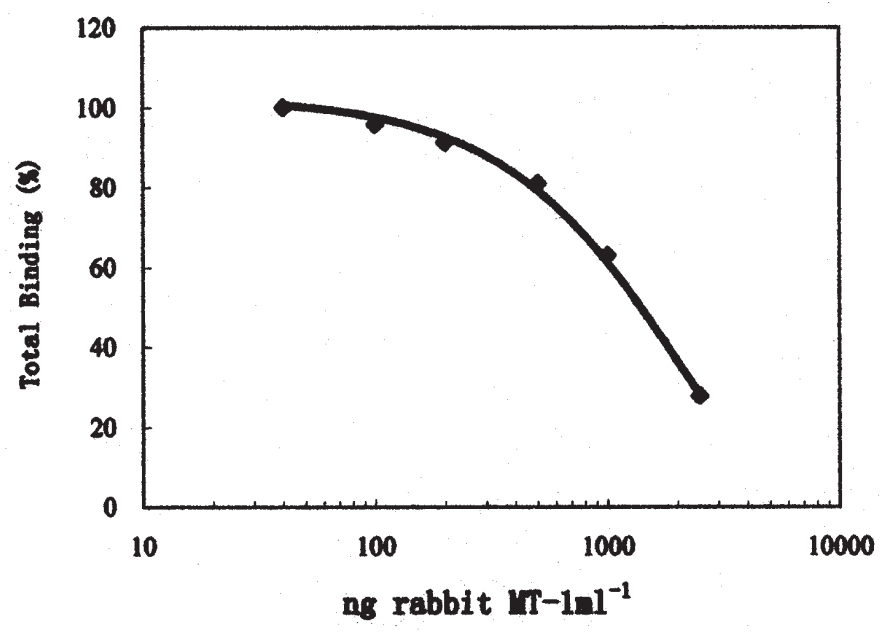

Figure 6. A purified rabbit MT-1 standard curve for competitive ELISA. coating concentration: $20 \mathrm{ng} / \mathrm{ml}$; antibody dilution: 1:2000; competitive purified rabbit MT-1 concentrations: $40-2500$ $\mathrm{ng} / \mathrm{ml}$ ).
Table I. Metallothionein contents of rabbit liver and kidney.

\begin{tabular}{lcc}
\hline Sample & Control & $\begin{array}{c}\text { High induction } \\
\text { group }\end{array}$ \\
\hline Liver $(\mu \mathrm{g} / \mathrm{g}$ wet weight tissue) & 240 & 3130 \\
Kidney $(\mu \mathrm{g} / \mathrm{g}$ wet weight tissue) & 200 & 3570 \\
\hline
\end{tabular}

Values are expressed as means $(n=2)$.

Table II. Protein concentration in rabbit erythrocyte lysate.

\begin{tabular}{|c|c|c|c|}
\hline & control & $\begin{array}{l}\text { Low } \\
\text { induction } \\
\text { group }\end{array}$ & $\begin{array}{c}\text { High } \\
\text { induction } \\
\text { group }\end{array}$ \\
\hline Protein concentration $(\mathrm{mg} / \mathrm{ml})$ & 72.42 & 69.44 & 25.47 \\
\hline
\end{tabular}

Values are expressed as means $(n=2)$.

It was guessed that rabbit species status lies between humans and rats, so MT level in the control rabbit liver is lower than that in the normal human liver, and higher than that in the normal rat liver. We prefer to use direct ELISA for estimation and quantification MT in crude tissue fractions, and this ELISA is also applicable in quantifying MT from freeze-drying powder.

\section{Use of competitive ELISA to determine metallothionein from erythrocyte lysates}

Determination of MT concentration in urine and blood has been found to be faced with difficulties which have not been encountered in tissue analyses. It is likely due to low MT concentration in them and difficult for MT to coat directly on ELISA plates, so we develop the competitive ELISA for erythrocyte lysate MT. ELISAs reported previously for MT have sensitivities of $100 \mathrm{pg}$ for fluorometric ELISA [19] and $15 \mathrm{ng}$ for ELISA [6] with alkaline phosphatease detection system. The sensitivity obtained by the rabbit erythrocyte lysate MT ELISA in this report was $2 \mathrm{ng}(40 \mathrm{ng} / \mathrm{ml})$. The sensitivity does not extend to the range obtained by fluorometric ELISA, but this assay is sensitive enough to quantify MT in the erythrocyte lysates. Therefore, this competitive ELISA could be used to assess zinc status in humans.

The optimal concentrations of rabbit MT-1 and rabbit anti-human MT-1 IgG concentrations used for the assay were determined experimentally (Fig. 5). Figure 6 shows that the coating concentration of $20 \mathrm{ng} / \mathrm{ml}$ and antibody dilution of 1:2000 with competitive rabbit MT-1 concentrations from 2-125 $\mathrm{ng}(40-2500 \mathrm{ng} / \mathrm{ml})$ can produce approximate linear changes in percent binding. To determine MT concentrations of unknown samples, data were transformed (logit Y) (Fig. 7). Protein concentrations of the erythrocyte lysates were determined (Tab. II) by an albumin standard 


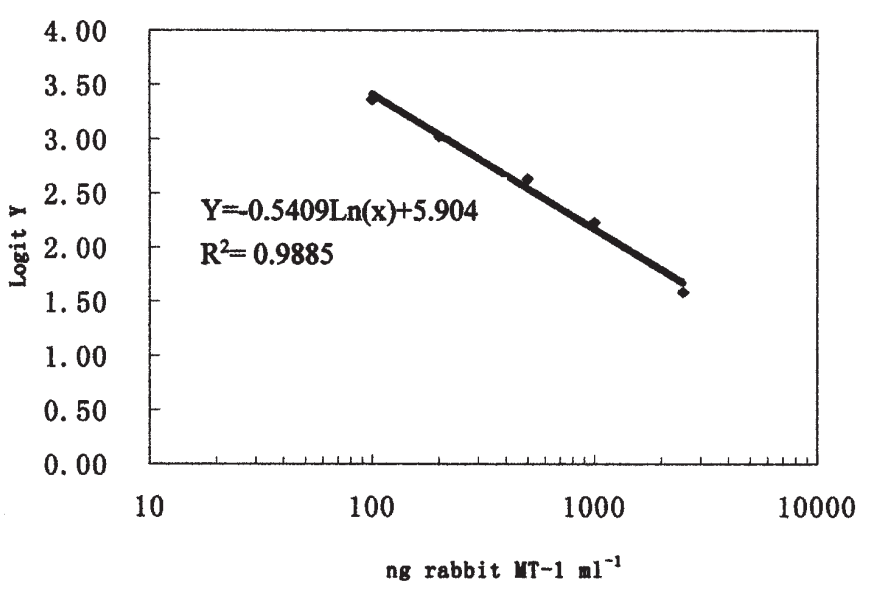

Figure 7. A purified rabbit MT-1 standard curve after logit $Y$ transformation: $\log 10([100 \times A e] /[A t-A e])$, where $A e$ is the aborbance of any MT standard and At is the total absorbance.

Table III. MT concentrations in rabbit erythrocyte lysates.

\begin{tabular}{lccc}
\hline & control & $\begin{array}{c}\text { Low } \\
\text { induction } \\
\text { group }\end{array}$ & $\begin{array}{c}\text { High } \\
\text { grouption }\end{array}$ \\
\hline $\begin{array}{l}\text { MT concentration } \\
(\mu \mathrm{g} / \mathrm{g} \text { total lysate protein) }\end{array}$ & 10.52 & 43.16 & 94.93 \\
\hline
\end{tabular}

Values are expressed as means $(n=2)$.

curve (Fig. 8). Table III shows that erythrocyte MT concentration in the control group averaged total lysate protein, it in the low induction group increased 4-fold (from $10.52 \mu \mathrm{g}$ $\mathrm{MT} / \mathrm{g}$ to $43.16 \mu \mathrm{g} \mathrm{MT} / \mathrm{g}$ protein) and it in the high induction group increased 9-fold (from $10.52 \mu \mathrm{g} \mathrm{MT} / \mathrm{g}$ protein to $94.93 \mu \mathrm{g} \mathrm{MT/g}$ protein). Arthur et al. reported that the normal human erythrocyte MT concentration averaged $40 \pm 6 \mu \mathrm{g} \mathrm{MT} / \mathrm{g}$ protein(SE), and it increased 7-fold (from $40 \pm 6 \mu \mathrm{g} \mathrm{MT} / \mathrm{g}$ protein to $273 \pm 85 \mu \mathrm{g} \mathrm{MT} / \mathrm{g}$ protein) by 7 days of supplementation at $50 \mathrm{mg}$ of zinc per day [6]. The disparity is probably attributable to species difference [6], zinc induction dose and induction time.

All these results show that direct ELISA can be used to quantify MT in rabbit tissues by induction of zinc; competitive ELISA can be used to determine their erythrocyte MT.

\section{Acknowledgements}

This work is supported by Chinese National 95 Plan Grant. It is a pleasure to acknowledge Professor Yu Ruiyuan for the purified rabbit MT-1.

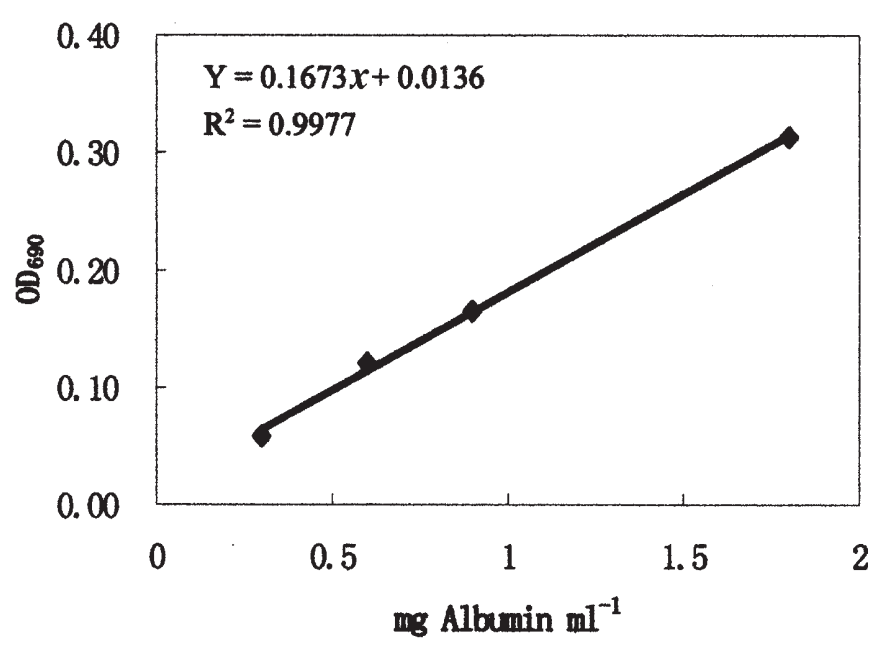

Figure 8. An albumin standard curve for protein concentration.

\section{References}

1. Kägi, J.H.R.; Schaffer, A. Biochemistry 1988, 27, 8509-8511.

2. Winger, D.R.; Miklossy, k.A. J. Biol. Chem. 1982, 257, 34713476 .

3. Schultze, P.; Worgotter, E.; Broun, W.M.; Wagner, G.; Vasak, M.; Kägi, J.H.R.; Wuthrich, K., J. Mol. Biol. 1988, 203, 251268.

4. Hamer, D.H. Annu. Rev. Biochem. 1986, 55, 913-951.

5. Tie, j.k.; Li, L.Y.; Ru, B.G.; Ci, Y.X. Acta. Biophys. Sinica 1995, 11, 276-282.

6. Arthur, G.; Lynn, B.B.; Robert, J.C. Proc. Natl. Acad. Sci. 1990, 87, 1259-1262.

7. Olafson, R.W.; Sim, R.G. Anal. Biochem. 1979, 100, 343-351.

8. Tie Feng; Pan Aihua; Ru Binggen; Li Lingyuan; Wang Wenqing Journal of Instrumental Analysis (in Chinese) 1993, 12(5), 18-22.

9. Dieter, H.H.; Müller, L.; Abel, J.; Summer, k.H. Toxicol. Appl. Pharmacol. 1986, 85, 380.

10. Onosaka, S.; Cherian, M.G. Toxicol. Appl. Pharmacol. 1982, 63, 270.

11. Eaton, D.L.; Toal, B.F. Toxicol. Appl. Pharmacol. 1982, 66, 134.

12. Piotrowski, J.R.; Bolanowska, W.; Saporta, A. Acta Biochem. Pol. 1973, 20, 207.

13. Lobel, P.B.; Payne, J.F. Comp. Biochem. Physiol. C: Comp. Pharmacol. Toxicol. 1987, 86c, 37.

14. Scheuhammer, A.M.; Cherian, M.G. Toxicol. Appl. Pharmacol. 1986, 82, 417.

15. Lehman, L.D.; Klassen, C.D. Anal. Biochem. 1986, 153, 305.

16. Richards, M.P. J. Chromatogr. 1989, 482, 87.

17. Suzuki, K.T. Anal. Biochem. 1980, 102, 31.

18. Canice, V.; Nolan; Zahir, A. Shaikh Anal. Biochem. 1986, 154(1), 213-223.

19. Thomas, D.G.; Linton, H.J.; Garvey, J.S. J. Immunol. Methods 1986, 89, 239-247. 
20. Mehra, R.K.; Bremner, I. Biochem. J. 1983, 213, 459.

21. Bremmer, I.; Mehra, R.K.; Sato, M. Experientia Suppl. 1987, 52, 507.

22. Hidalgo, J.; Giralt, M.; Garvey, J.S.; Armario, A. J. Physiol. 1988, 254, E71.

23. Vasak, M. Methods in Enzymology 1991, 205, part B, 41-43.

24. Arthur, G.; Kuo, J.K. J. Lab. Clin. Med. 1989, 113, 221-228.

25. Wang, Y.Y.; Ren, H.W.; Wang, W.Q.; Pan, A.H.; Li, L.Y.; Ru, B.G.; J. Environ. Sci. 1995, 7, 407-413.
26. Lowry, O. et al. J. Biol. Chem. 1951, 193, 265.

27. Garvey, J.S. Environ. Health Perspect. 1984, 54, 117.

28. Norderg, M. Talanta 1998, 46, 243-254.6.

29. Onosaka, S.; Min, K.S.; Fukuhara, C. et al. Toxicology 1986, 38, 261-268.

30. Chung, J.; Nartey, N.O.; Cherian, M.G. Arch. Environ. Health 1986, 41, 319-323. 